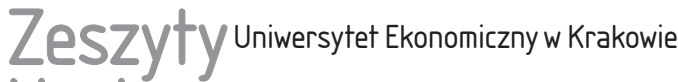 Naukowe
}

\section{Deklaracja społecznej odpowiedzialności uczelni jako wzmocnienie etosu akademickiego}

\section{Streszczenie}

16 listopada 2017 r. przedstawiciele 23 uczelni w Polsce podpisali Deklaracje społecznej odpowiedzialności uczelni. Deklaracja w dwunastu punktach określa zasady związane ze społeczną odpowiedzialnością uczelni. Przyczyn rosnącego znaczenia koncepcji społecznej odpowiedzialności uczelni można upatrywać w malejącym znaczeniu etosu akademickiego. Zbiór wartości zawartych w etosie akademickim powinien stanowić wyznacznik działań podejmowanych przez uczelnie, stąd jego osłabienie budzi pewien niepokój. Rozwijająca się koncepcja społecznej odpowiedzialności uczelni stwarza szansę na podtrzymanie tych wartości. Celem artykułu jest próba odnalezienia wartości wspólnych dla etosu akademickiego i Deklaracji społecznej odpowiedzialności uczelni. Przeprowadzona analiza pozwala stwierdzić, że popularyzacja koncepcji społecznej odpowiedzialności uczelni została wzmocniona poprzez deklarację, która w dużej mierze odnosi się do etosu akademickiego.

Słowa kluczowe: odpowiedzialność społeczna, uniwersytet, wartości, misja, etos akademicki.

Klasyfikacja JEL: I23, I20, I21. 


\section{Wprowadzenie}

W ostatnich latach coraz większą wagę przywiązuje się do koncepcji społecznej odpowiedzialności uczelni. Przyczyną tego zjawiska może być malejące znaczenie etosu akademickiego. Zbiór wartości zawartych w etosie akademickim powinien stanowić wyznacznik działań podejmowanych przez uczelnie, stąd jego osłabienie budzi pewien niepokój. Rozwijająca się koncepcja społecznej odpowiedzialności uczelni stwarza szansę na podtrzymanie tych wartości. Ze względu na swój charakter nie stanowi ona natomiast nowego tworu, lecz ma podstawy w etosie akademickim.

Zagadnienia związane z etosem akademickim stają się kluczowe w debacie nad przyszłością nauki, kiedy uświadomimy sobie jego istotę. Stanowi on fundament nauki, bez którego funkcjonowanie środowisk akademickich nie byłoby możliwe. Pojawiają się jednak pytania o jego aktualność i miejsce w dzisiejszym szkolnictwie. Pomimo takich pełnych obaw wizji etos akademicki jest wymieniany w Polskiej Ramie Kwalifikacji (PRK). W kontekście kształtowania kompetencji społecznych doktorantów w PRK zakłada się, że doktorant, a więc młody adept nauki, będzie gotów do „podtrzymywania i rozwijania etosu środowisk badawczych i twórczych, w tym: prowadzenia badań w sposób niezależny, respektowania zasady publicznej własności wyników badań naukowych z uwzględnieniem zasad ochrony własności intelektualnej" (Chłon-Domińczak i in. 2017). Oczekiwania takie otwierają zatem pewną furtkę dla uczelni i pozostawiają w ich zakresie przestrzeń do dyskusji o etosie akademickim (Chmielecka 2017).

Celem artykułu jest próba wskazania wartości wspólnych dla etosu akademickiego i Deklaracji społecznej odpowiedzialności uczelni, która została podpisana przez przedstawicieli 23 uczelni w Polsce 16 listopada $2017 \mathrm{r}$. W badaniu zostały wyodrębnione wartości utożsamiane z etosem akademickim, a następnie skonfrontowano je z punktami deklaracji.

\section{Etos akademicki i jego znaczenie}

Uniwersytet od momentu powstania stanowił instytucję szczególną. Odróżniał się od innych podmiotów wartością centralną, którą była apoteoza rozumu (Sztompka 2016). Uniwersytet skupia osoby wokół pewnych wartości podstawowych. Ten zbiór wartości wyznacza trwałość uniwersytetu oraz odporność na czynniki mogące go zniszczyć. Uniwersytet stanowi instytucję niezbędną do funkcjonowania społeczeństw i ich rozwoju. Zawsze był wierny swoim wartościom wewnętrznym i nie ulegał naciskom, co odróżniało go od innych organizacji (Brzeziński 2011). Wyjątkowość uniwersytetu przejawia się również w jego trwa- 
łości. Wszystkie inne podmioty przemijały, a uniwersytety, często nawet w tych samych budynkach, trwały niezmiennie (Kerr 2001).

Klasyczne ujęcie etosu nauki zawdzięczamy R. Mertonowi. Wyznaczył on normy tworzące etos nauki oraz wartości, na których opiera się nauka. Do norm zaliczył: uniwersalizm, wspólnotę (komunalizm), bezinteresowność oraz zorganizowany sceptycyzm. Uniwersalizm utożsamiał z możliwością rozpoczynania rozwoju naukowego przez każdą osobę mającą do tego predyspozycje, a w kontekście twierdzeń naukowych przez uniwersalizm rozumiał przyjmowanie prawdziwych twierdzeń bez względu na to, skąd pochodzą. Wspólnota w ujęciu R. Mertona odnosiła się do tego, że odkrycia naukowe są własnością wszystkich, którzy są nimi zainteresowani. Bezinteresowność oznaczała podejmowanie działań mających na celu poszukiwanie prawdy w oderwaniu od innych czynników mogących przynosić korzyści. Zorganizowany sceptycyzm polegał natomiast na głoszeniu tylko tego, na co są dostateczne dowody (Szacki 1989). R. Merton stwierdził również, że nauka opiera się na wartościach wywodzących się z norm - „wolności i otwartości wymiany wiedzy, niczym nieskrępowanym i bezinteresownym poszukiwaniu prawdy, przekonaniu, że to natura jest najważniejszą instancją rozstrzygającą spory na temat świata fizycznego. Merton uważał, że wartości te są powszechnie akceptowane w obszarze nauki i tworzą jego zdaniem etos naukowy" (Bieliński 2016).

Obserwując funkcjonowanie uniwersytetu w ostatnich latach, można zauważyć, że coraz większą ilość zadań i odpowiedzialność przypisuje się tej instytucji. Są to funkcje związane ze służebnością - zarówno wobec interesariuszy wewnętrznych: kadr i studentów, jak i otoczenia społecznego; z funkcjami poznawczymi, takimi jak poszukiwanie prawdy w obecnej rzeczywistości oraz prowadzenie badań, wobec których nie widzimy dziś zastosowania; z kształceniem - tak, aby absolwenci potrafili funkcjonować na rynku pracy przez całą swoją karierę zawodową oraz byli uczestnikami życia społecznego. Zebranie wszystkich funkcji uczelni, jak twierdzi E. Chmielecka (2008, s. 23), jest możliwe poprzez pojęcie etosu akademickiego, określającego „zbiór wartości, którym podporządkowane jest życie szkoły wyższej we wszystkich jego wymiarach, przyjętych jako aksjologiczne uzasadnienie postaw i działań w środowisku akademickim". Ponadto autorka uważa, że etos akademicki jest konieczny do istnienia nauki oraz stanowi fundament wspólnoty akademickiej - jak stwierdza: „wyodrębniam zbiór fundamentalnych wartości, które ten etos akademicki, właściwy dla wspólnoty, konstytuują, które nadają tej wspólnocie tożsamość i bez których ta wspólnota po prostu znika. Warunkiem bowiem istnienia wspólnoty jest dobro wspólne w postaci zbioru wartości autotelicznych, wokół których ta wspólnota się organizuje" (Chmielecka 2008, s. 23). Wartości wyznaczane przez etos akademicki są kultywowane i strzeżone przez wspólnotę. Autoteliczną wartość etosu stanowi prawda - w badaniach naukowych, w nauczaniu i w rozwiązaniach kierowanych 
do całych społeczności. Etos akademicki jest również uniwersalny w rozumieniu różnorodności szkół wyższych, w których funkcjonuje. Bez względu na profil uczelni wartości nadrzędne w każdej z nich powinny być takie same i tożsame z tymi, które przypisujemy do etosu akademickiego. Spójna struktura etosu akademickiego dla każdej uczelni wynika również z tego, że tworzą go wartości związane z misją tej uczelni. Mowa tu zatem o wartościach etycznych, epistemicznych oraz pragmatycznych i społecznych (Morawski 2017).

Etos akademicki, rozumiany jako podstawa tożsamości oraz spoiwo wspólnoty akademickiej, która realizuje dwa podstawowe zadania: badania oraz kształcenie, przez wieki regulował funkcjonowanie społeczności akademickiej oraz był podstawą misji uniwersytetu. $Z$ tego względu „erozja” etosu akademickiego budzi obawy i skłania do refleksji środowisko akademickie. Zniknięcie etosu jest jednoznaczne z końcem istnienia uniwersytetów w tradycyjnym ujęciu, opartych na wartościach i wzniosłym celu (Program rozwoju... 2015). Wzmagające się naciski ze strony środowiska zewnętrznego skutkują ograniczaniem autonomii uniwersytetu. Sytuacja ta zmusza do dyskusji i poszukiwania rozwiązania umożliwiającego ocalenie fundamentalnych wartości, na których opiera się uniwersytet. Wydaje się przy tym, że otoczenie społeczno-gospodarcze bezpowrotnie przedefiniowało miejsce uniwersytetu w społeczeństwie (Gaweł 2017b).

\section{Zagrożenia instytucjonalne etosu akademickiego}

Największe zagrożenia etosu akademickiego wynikają z rozwiązań instytucjonalnych powiązanych z naukową misją uniwersytetu. Mowa tu zatem o wyznaczonych przez R. Mertona zagrożeniach dotyczących fundamentów nauki: komunalizmie, uniwersalizmie, bezinteresowności i zorganizowanym sceptycyzmie. Pojawia się ponadto zróżnicowany poziom zagrożenia w poszczególnych ośrodkach, jednak wynika on nie z samej definicji etosu, którą przyjmujemy za uniwersalną, tylko z profilu działalności ośrodka. W literaturze przedmiotu wymieniane są trzy podstawowe zagrożenia instytucjonalne: ilościowe podejście do pomiaru efektywności nauki, grantowy model prowadzenia badań przez naukowców, sposób dwuskładnikowego wynagradzania pracowników naukowych (Morawski 2017).

Podejście ilościowe do pomiaru efektywności nauki P. Sztompka (2017) określa „kwantofremią”. Zastosowanie wskaźników ilościowych i wszelkich policzalnych miar przeczy wspólnocie świata nauki, w której środowisko we własnym zakresie potrafi ocenić wartość nauki, wykorzystując metody jakościowe oraz podchodząc w sposób całościowy do osiągnieć. Podobnie wygląda kwestia związana z bibliometrią, w której funkcjonują kryteria biurokratyczne, oderwane od potrzeb i specyfiki polskiej nauki. Miary te w dużym stopniu dyskredytują nauki 
humanistyczne oraz zagadnienia związane z kontekstem polskim, gdyż trudno o publikacje z tego zakresu w czasopismach zagranicznych, co najlepiej wyglądałoby w ocenie parametrycznej (Sztompka 2017).

Podejmując się analizy zagrożeń etosu akademickiego, R. Morawski używa bardzo dosadnej parafrazy. Mianowicie tytuł powieści G.G. Márqueza Miłość w czasach zarazy odnosi do nauki w tytule jednego ze swoich artykułów: Nauka $w$ czasach biurokracji. Tytuł ten pokazuje, jak naukowcy, dla których nauka jest miłością, spotykają się z niespełnieniem za sprawą biurokracji. R. Morawski używa również barwnej metafory, określając biurokrację motylem morskim, który dba o pozory, potrafi przypodobać się silniejszym, a swoją siłę pokazuje w odniesieniu do słabszych. Autor przypisuje biurokracji wymienione wcześniej trzy podstawowe zagrożenia dotyczące nauki. Pierwsze zagrożenie nazywa ,punktozą” i zarzuca tej metodzie nieadekwatność do specyfiki środowiska akademickiego. Drugie zagrożenie, związane z pozyskiwaniem środków na realizację badań, autor nazywa ,grantozą". Rozwiązaniu temu przypisuje zarzut indywidualnego charakteru, oddalającego naukowców od tworzenia zespołów badawczych. Co więcej, w momencie, kiedy tego tupu rozwiązania były wprowadzane w Polsce, w Stanach Zjednoczonych już można było zaobserwować negatywne następstwa takiego sposobu finansowania badań. Kwestia grantów ściśle związana jest również z ogromną biurokracją - od momentu ubiegania się o finansowanie, poprzez proces trwania grantu, do jego rozliczenia i zamknięcia. Pomimo że teoretycznie w ramach uczelni funkcjonują jednostki zajmujące się wsparciem takich przedsięwzięć, to i tak ogromną pracę administracyjną wykonuje naukowiec. Problemem jest tutaj również perspektywa badawcza, która najczęściej ogranicza się do czasu trwania projektu (Morawski 2016). Problematyczne jest także to, że w procesie pozyskiwania środków na badania na gorszej pozycji stoją nauki humanistyczne i społeczne, które często określane są mianem mało użytecznych społecznie. Nie prowadzą do spektakularnych osiągnieć ani wynalazków, jednak ich istota tkwi w poszukiwaniu większego sensu. Badań z zakresu nauk humanistycznych i społecznych nie można dostosować do krótkoterminowych zadań, które oczekiwane są w projektach grantowych (Gaweł 2017a).

Trzecie zagrożenie związane jest natomiast ze sposobem wynagradzania naukowców. Często bowiem pracownikom naukowym oferowana jest bardzo niska podstawa, która uzupełniana jest honorarium wynikającym z prowadzenia grantów. Sytuacja ta powoduje, że pobudkami do prowadzenia badań nie są tylko kwestie związane z poszukiwaniem prawdy i dociekliwością badawczą, co podważa bezinteresowność, wymienianą jako podstawową wartość w etosie akademickim (Morawski 2016).

Zasadniczo zagrożeniem etosu akademickiego jest zastąpienie go etosem korporacyjnym. Będzie on wówczas spełniał zasady policzalności, a jego celem 
będzie zwiększanie efektywności. Przeniesienie zasad korporacyjnych do uczelni niesie za sobą jednak poważne zagrożenie kultury akademickiej. Sprowadzenie uniwersytetu do instytucji, która będzie wypełniać zadania dyktowane przez rynek, wykluczy nieskrępowane poszukiwanie prawdy, a także kształtowanie relacji mistrz-uczeń (Program rozwoju... 2015).

\section{Etosy akademickie w Polsce}

W historii szkolnictwa wyższego był już czas wzmożonej dyskusji o etosie akademickim, która rozpoczęła na początku XXI w. Powodem takiego zainteresowania była obawa przed nadmierną komercjalizacją nauki. Okazuje się, że dyskusje o etosie akademickim są prowadzone, kiedy pojawia się presja ze strony środowiska zewnętrznego. W momencie względnej stabilności etos funkcjonuje w świadomości społeczności akademickiej (Chmielecka 2017). Na początku XXI w. powstało wiele kodeksów ogólnych oraz uczelnianych. W ramach kodeksów ogólnych w 2001 r. powstał kodeks wydany przez Komitet Etyki w Nauce działający przy Polskiej Akademii Nauk pt. Dobre obyczaje w nauce. Zbiór zasad i wytycznych. W 2004 r. został opublikowany dokument Dobra praktyka badań naukowych. Rekomendacje, opracowany przez Zespół Etyki w Nauce przy Ministrze Nauki. W 2007 r. pojawiła się publikacja przygotowana przez Fundację Rektorów Polskich Dobre praktyki w szkołach wyższych. Określonych zostało w niej dziesięć fundamentalnych zasad, którymi powinny się kierować uniwersytety (Dobre praktyki w szkołach wyższych... 2007):

1) zasada służby publicznej - odnosi się ona do działalności uczelni dla dobra społeczeństwa poprzez rzetelne prowadzenie badań, a także kształcenie przyszłych elit;

2) zasada bezstronności w sprawach publicznych - uczelnia jako instytucja posiadająca ogromny autorytet, powinna kierować się w sprawach publicznych bezstronnością oraz obiektywizmem;

3) zasada legalizmu - zasada ta przypomina o bezwzględnej konieczności poszanowania prawa przez uczelnie oraz kształtowania kultury prawa pośród studentów;

4) zasada autonomii i odpowiedzialności - w ramach autonomii uczelnia powinna wyznaczać swoją misję, tak aby efektywnie podejmować zadania na rzecz społeczeństwa oraz z odpowiedzialnością za dobro wspólne;

5) zasada podziału i równowagi władzy na uczelni - dotyczy ona podziału władzy oraz niezależności pomiędzy rektorem a senatem;

6) zasada kreatywności - dotyczy podejmowania inicjatyw w myśl rozwoju uczelni w sposób strategiczny; 
7) zasada przejrzystości - dotyczy jawności i sprawiedliwości w konkursach i awansach, a także w przyznawaniu nagród, w procedurach badawczych itp.;

8) zasada subsydiarności - związana jest $\mathrm{z}$ koniecznością przestrzegania zasady pomocniczości, zgodnie z którą należy respektować przedsięwzięcia niższych organów władzy; dotyczy również przestrzegania drogi służbowej w wypełnianiu zadań na uczelni;

9) zasada poszanowania godności i tolerancji - odnosi się do szacunku wobec wszystkich rodzajów poglądów oraz postaw i stylów życia, które są dopuszczone prawem;

10) zasada uniwersalizmu badań i kształcenia - uniwersytet jako instytucja powszechna uczestniczy w procesie badań i kształcenia w nauce światowej i dba o dobro ludzkości.

W 2009 r. opublikowany został Kodeks etyki Państwowej Komisji Akredytacyjnej, wydany przez Prezydium Państwowej Komisji Akredytacyjnej, natomiast w 2017 r. - najnowszy kodeks: Kodeks etyki pracownika naukowego, stworzony przez Komisję do spraw Etyki w Nauce działającą przy Polskiej Akademii Nauk.

Czas wzmożonego zainteresowania tworzeniem kodeksów akademickich skutkował również powstaniem tego typu dokumentów w ramach poszczególnych uczelni. Pośród najpopularniejszych kodeksów tworzonych przez uczelnie wyróżniamy: Akademicki kodeks wartości Uniwersytetu Jagiellońskiego, Kodeks etyki pracowników Politechniki Wrocławskiej, Akademicki kodeks etyczny Akademii Górniczo-Hutniczej, Kodeks etyki pracownika naukowego Politechniki Śląskiej, Akademicki kodeks etyczny Akademii Wychowania Fizycznego we Wrocławiu, Kodeks etyki nauczyciela akademickiego Uniwersytetu Gdańskiego i Kodeks etyki Akademii Leona Koźmińskiego (Nowakowski 2011).

Jednym z najpopularniejszych kodeksów jest Akademicki kodeks wartości, uchwalony przez Senat Uniwersytetu Jagiellońskiego w czerwcu 2003 r. W jego preambule wprost określone są przyczyny spisania kodeksu. Podkreśla się fakt narastających zagrożeń, sprawiających, że konieczne jest przypomnienie wartości, które tworzyły autorytet w nauce oraz wyrażały siłę moralną świata akademickiego. W kodeksie wymienionych zostało jedenaście wartości podstawowych. Pierwsza z nich to prawda - w kodeksie odniesiono się do poszukiwania jej oraz głoszenia i wychowania studentów w jej duchu. Drugą wartością jest odpowiedzialność. Mowa tu o odpowiedzialności za warsztat naukowy, całą dyscyplinę, instytucję i swoje środowisko. Odpowiedzialność dotyczy również wychowania, implementacji wyników badań oraz zaangażowania w życie akademickie. Trzecią wartość stanowi życzliwość, która dotyczy w szczególności relacji mistrz-uczeń oraz atmosfery panującej na uniwersytecie. Kolejna wartość wymieniona w Akademickim kodeksie wartości to sprawiedliwość, rozumiana przede wszystkim w kontekście oceniania zarówno studentów, jak i pracow- 
ników. Następną wartością jest rzetelność. Odnosi się ona do pracy naukowca, która powinna być solidna i oderwana od chwilowych rozumowań niepopartych metodologicznie. Wśród wartości podstawowych wymieniana jest również tolerancja. Dotyczy ona zarówno poglądów, opinii, kultury, koncepcji, jak i wyzbycia się dyskryminacji wobec ludzi. Siódmą wartością jest lojalność, która powiązana jest ze wspólnotowością - to lojalność względem wspólnoty akademickiej. Ósma wartość to samodzielność, wiążąca się z poszanowaniem własności intelektualnej. W punkcie tym podnoszony jest problem nieuczciwej pracy naukowej opartej na plagiacie i innych formach kradzieży intelektualnej, które w myśl zasady samodzielności są niedopuszczalne w środowisku akademickim. Następna wartość wyszczególniona w kodeksie to uczciwość. Odnosi się ona do jawności warsztatu badacza, a także uczciwości wobec studentów, którym wykładowca powinien przekazywać najnowsze wyniki badań. Przedostatnią wartością wymienioną w Akademickim kodeksie wartości jest godność, o którą w odniesieniu do uniwersytetu należy dbać nie tylko w stosunku do pracowników naukowych, ale każdego zatrudnionego. Stanowi ona fundamentalną wartość każdego człowieka. Ostatnia wartość to wolność nauki - wolność uczonych, argumentowa tym, że wartości etyczne mają szansę funkcjonowania tylko w społecznościach, gdzie ludzie są wolni (Akademicki kodeks wartości... 2003).

W tym samym roku co kodeks Uniwersytetu Jagiellońskiego powstał Akademicki kodeks etyczny Politechniki Wrocławskiej, jednak w 2016 r., został on zastąpiony Kodeksem etyki pracowników Politechniki Wrocławskiej. W pierwszym rozdziale zawiera on powinności pracowników Politechniki Wrocławskiej. W drugim rozdziale wyszczególniono natomiast powinności władz Politechniki Wrocławskiej, pracowników naukowo-badawczych, pracowników naukowych oraz nauczycieli akademickich. Sklasyfikowane są one kolejno w trzech punktach: powinności dotyczące dydaktyki i wychowania, powinności dotyczące badań naukowych, powinności dotyczące organizacji i administracji. Powinności wymienione w dwóch pierwszych punktach Kodeksu etyki pracowników Politechniki Wrocławskiej są spójne treściowo z Akademickim kodeksem wartości Uniwersytetu Jagiellońskiego. Pewnego rodzaju nowością są niektóre elementy z trzeciego punktu, jak konieczność dbałości o sprawną organizację uczelni, efektywne zarządzanie wszystkimi rodzajami aktywności i przejrzystość podejmowanych działań (Kodeks etyki... 2016).

W 2003 r. został opublikowany również Akademicki kodeks etyczny Akademii Górniczo-Hutniczej, który w dziewięciu zwięzłych punktach zawiera zasady, jakimi kieruje się środowisko naukowe uczelni. Ich treść odwołuje się do podstawowych wartości, takich jak: lojalność, sumienność, uczciwość, rzetelność, życzliwość i samodzielność. W kodeksie tym mowa jest również o korzystaniu z dóbr 
AGH tylko do celów związanych z pracą na uczelni, unikaniu konfliktu interesów mogących godzić w autorytet uczelni, podnoszeniu poziomu zrozumienia społecznego prowadzonej działalności naukowej i badawczej oraz konieczności sprzeciwiania się patologiom zarówno w środowisku akademickim, jak i społecznym (Akademicki kodeks etyczny... 2003).

Na szczególną uwagę zasługuje również proces spisywania etosu akademickiego z inicjatywy Szkoły Głównej Handlowej, trwający od 2003 r. Do tego projektu dołączyły inne uczelnie ekonomiczne. Cykl spotkań skutkował wyodrębnieniem wartości etosu akademickiego z podziałem na trzy grupy. Pierwsza z nich dotyczy wartości akademickich związanych z podstawowymi celami nauki oraz nauczania. Wymienione zostały tutaj trzy wartości: prawda - jako wartość fundamentalna, odpowiedzialność - w badaniach i dydaktyce, oraz rzetelność - w pracy naukowej. Druga grupa związana jest z funkcjonowaniem wspólnoty akademickiej w uwarunkowaniach instytucjonalnych. Wartości w niej zawarte zostały podzielone na kategorie zobowiązań. W ramach zobowiązań wspólnoty akademickiej oraz uczelni wyszczególnione zostały dążenie do prawdy i jej głoszenie przez naukowców z wykorzystaniem swobody, a ze strony uczelni zapewnienie owej wolności. Kolejne zobowiązania dotyczą wspólnoty akademickiej oraz władzy instytucji. Wspólnota powinna dbać o wszystkich swoich członków, a także przedkładać dobro wspólnoty ponad indywidualne interesy, istotne są również lojalność i poczucie odpowiedzialności za reprezentowaną jednostkę. Uczelnia w rozumieniu instytucjonalnym powinna natomiast stwarzać możliwości rozwoju oraz dbać o dobro wspólne i etos. Następne zobowiązania dotyczą wspólnoty akademickiej oraz władzy uczelni. W tym zakresie wymieniane są sumienność członków wspólnoty w ramach wypełnianych obowiązków oraz podejmowanie badań i debaty na tematy ważne społecznie $\mathrm{i}$ istotne w nauce. Ze strony władz natomiast zobowiązania dotyczą zapewnienia dobrych warunków do pracy oraz odpowiedniego wynagrodzenia, a także wspierania inicjatyw wspólnoty i stwarzania możliwości debaty. W grupie tej dostrzeżona została również rola społeczności studenckiej. Ostatnia, trzecia grupa wartości odnosi się do relacji mistrz-uczeń. W ramach licznych zasad w tej grupie wymienić można następujące: poszanowanie wszystkich członków wspólnoty, obrona etosu akademickiego, troska o rozwój naukowy i wychowanie studenta, dbałość o rozwój naukowy nauczyciela akademickiego, aktualność badań, sumienne podchodzenie do obowiązków, przejawiające się m.in. w przygotowaniu do zajęć, punktualności i terminowości, sprawiedliwym ocenianiu, tolerancji, życzliwości i opiekuńczości (Etos akademicki... 2004). 


\section{Deklaracja społecznej odpowiedzialności uczelni}

16 listopada 2017 r. przedstawiciele 23 uczelni w Polsce podpisali Deklaracje społecznej odpowiedzialności uczelni, która jest efektem prac Grupy roboczej ds. edukacji i popularyzacji CSR, funkcjonującej w ramach Zespołu ds. Zrównoważonego Rozwoju i Społecznej Odpowiedzialności Przedsiębiorstw, będącej organem pomocniczym Ministra Rozwoju i Finansów (Deklaracja społecznej... 2017). Fakt ten stanowi wyraz wzrastającego zainteresowania społeczną odpowiedzialnością uczelni, ponadto została wyrażona wola podpisania deklaracji przez przedstawicieli kolejnych ośrodków, co stwarza perspektywę dalszego rozwoju tego przedsięwzięcia. Deklaracja w dwunastu punktach zawiera zasady związane ze społeczną odpowiedzialnością uczelni. Podkreślono rolę wartości w nauce, wskazując ich miejsce w zadaniach podejmowanych przez uczelnie. Zwrócono uwagę na istotne znaczenie wartości w obszarze prowadzenia badań i dydaktyki oraz w procesie propagowania idei odpowiedzialności społecznej i rozwiązywania problemów społecznych, a także wskazano wartości dotyczące zarządzania zadaniami na uczelni oraz związane z kształtowaniem relacji z interesariuszami. Pomimo że sama deklaracja jest nową inicjatywą, to wartości wynikające z jej punktów wydają się bardzo dobrze znane środowisku naukowemu.

Pierwszy punkt Deklaracji społecznej odpowiedzialności uczelni (Deklaracja społecznej... 2017) odwołuje się do Kodeksu etyki pracownika naukowego, wskazując jednocześnie, że przestrzeganie innych kodeksów jest również istotne. Ze wspomnianego kodeksu wymieniono pięć z jedenastu wartości, które uznano za szczególnie istotne. Są to: sumienność, niezależność, obiektywizm, przejrzystość i otwartość. Punkt ten jest zatem całkowicie spójny z omawianymi kodeksami. Drugi punkt deklaracji związany jest z kształtowaniem elit. Wymieniane są tutaj również dobrze znane wartości, jak: otwartość, wrażliwość, kreatywność, kultura pracy, a także kształtowanie postaw społecznych i obywatelskich. Treść tego punktu jest odzwierciedleniem tego, co we wcześniejszych rozważaniach nazywane było częścią etosu akademickiego, stanowiącą jedno z zadań uniwersytetu. Trzeci punkt deklaracji związany jest z zarządzaniem różnorodnością. Podnoszona jest tu kwestia tolerancji i równości w kontekście całej społeczności akademickiej i jej otoczenia. Aspekt tolerancji poruszany był chociażby w Akademickim kodeksie wartości Uniwersytetu Jagiellońskiego oraz stanowi jedną z zasad fundamentalnych kodeksu przygotowanego przez Fundację Rektorów Polskich. Czwarty punkt deklaracji odnosi się do edukacji w zakresie etyki, odpowiedzialności, zrównoważonego rozwoju i innowacji społecznych. W kodeksach etycznych tworzonych przez uczelnie wymieniane było kierowanie się odpowiedzialnością i zachowaniami etycznymi, a także kształtowanie takich postaw pośród uczniów. Nie występowały natomiast sformułowania związane ze zrównoważonym 
rozwojem i innowacjami społecznymi. W pewnym zakresie sformułowania te można przypisać do zasady służby publicznej w publikacji Dobre praktyki w szkołach wyższych, jednak w deklaracji mowa również o edukacji w tym zakresie, co powoduje, że te elementy stanowią pewne uzupełnienie treści zawartych w kodeksach etycznych. W piątym punkcie deklaracji pojawia się kwestia aktywności podejmowanych przez uczelnie. O ile w kodeksach odnajdujemy odniesienia do uczestnictwa w debacie społecznej i inicjowania jej na ważne tematy dla całego społeczeństwa, o tyle w punkcie tym jest mowa o zaangażowaniu organizatorskim w bardziej zaawansowany sposób. W pierwszej części wymieniane jest tutaj wdrażanie projektów związanych z zasadami społecznej odpowiedzialności z naciskiem na zarządzanie różnorodnością w miejscu pracy. W kodeksach etycznych podkreśla się poszanowanie godności drugiego człowieka i otwartość, chociażby w Kodeksie etyki pracownika naukowego. Podobnie sytuacja wygląda z odpowiedzialnością, która występuje przykładowo w ujęciu etosu akademickiego spisywanego z inicjatywy SGH. Odpowiedzialność określana była w nim na wielu płaszczyznach, w tym jako odpowiedzialność za całą wspólnotę. W drugiej części omawianego piątego punktu deklaracji jest mowa o wolontariacie pracowniczym, którego przejawy widzimy również w zasadzie służby publicznej - zgodnie z tą zasadą misja uczelni powinna nosić znamiona działalności pro publico bono. Szerzej ujęto natomiast wolontariat kompetencyjny, który jest jedną z odmian wolontariatu pracowniczego. W ramach wolontariatu kompetencyjnego pracownicy danej organizacji dzielą się wiedzą i umiejętnościami z zakresu, w którym wykonują swoją pracę. W przypadku nauczycieli akademickich będzie to zatem dzielenie się wiedzą ze swojej dyscypliny naukowej oraz poświęcanie czasu młodym adeptom nauki. W etosie akademickim spisywanym $\mathrm{z}$ inicjatywy SGH odnajdujemy w relacji mistrz-uczeń zapisy związane z opiekuńczością, tolerancją, inspirowaniem studentów czy indywidulanym traktowaniem. Cała narracja odnosi się jednak do prowadzonych zajęć, nie ma tutaj mowy o aktywnościach wykraczających ponad to, co obowiązkowe, więc nie można powiedzieć, że są to zasady dotyczące wolontariatu kompetencyjnego. Następnie w omawianym punkcie wymieniana jest promocja zasad etyki, o której jest mowa we wszystkich kodeksach. Podstawą funkcjonowania środowiska akademickiego jest etyka i kodeksy podkreślają konieczność kształtowania postaw etycznych wśród studentów w procesie edukacji. W piątym punkcie deklaracji wymieniana jest również współpraca międzysektorowa oraz marketing społecznie zaangażowany. Takie sformułowania nie padają wprost w analizowanych kodeksach, jednak współpraca międzysektora w wymiarze współpracy z organizacjami pozarządowymi jest poniekąd tożsama ze współpracą ze społeczeństwem, co do którego w kodeksach poruszana była kwestia uczestnictwa w debacie w zakresie problemów szczególnie istotnych. Deklaracja wyznacza zatem nowe zadanie dla uczelni, które będzie 
realną współpracą, wypracowywaniem wspólnych rozwiązań w ramach współpracy międzysektorowej. Dotyczy ona także pierwszego i drugiego sektora, a więc instytucji państwa i podmiotów gospodarczych. W kontekście tych podmiotów kodeksy etyki nie wymieniały sposobów współpracy ani nie podejmowały kwestii marketingu społecznie zaangażowanego. Wprowadzenie takich powinności w deklaracji stanowi określenie zadań przystosowanych do obecnej rzeczywistości społeczno-gospodarczej, w której współpraca międzysektorowa pozwala efektywnie realizować cele wielu podmiotów, a marketing społecznie zaangażowany przynosi korzyści nie tylko dla pomysłodawcy, ale i dla otoczenia społecznego. Szósty punkt deklaracji dotyczy podejmowania badań naukowych w ramach współpracy międzysektorowej oraz z innymi uczelniami w wymiarze globalnym, co może przynieść rozwiązania istotnych problemów społecznych. Punkt ten stanowi novum w odniesieniu do etosu akademickiego, który wymieniał prowadzenie badań z myślą o rozwiązywaniu problemów społecznych, jednak nie uwzględniał realizacji tego zadania $w$ ramach partnerstwa. Podobnie wygląda sytuacja z siódmym punktem dotyczącym współpracy między uczelniami w celu wzmacniania dobrych praktyk w obrębie społecznej odpowiedzialności uczelni. W kodeksach była mowa o wspólnocie w ramach jednej jednostki, natomiast nie była poruszana kwestia rozszerzenia tej wspólnoty na inne uczelnie - choć proces spisywania wartości etosu akademickiego przez uczelnie ekonomiczne jest przejawem takiego działania, to w sposób literalny nie zostało ono zapisane. Ciekawie sformułowany jest ósmy punkt deklaracji dotyczący dbałości o ład organizacyjny, uwzględniono bowiem zasady społecznej odpowiedzialności uczelni. W kodeksach wstęp czy preambuła formułowane były w podobnym tonie, ale w ich przypadku chodziło o uwzględnienie zasad na podstawie etosu akademickiego. Punkt ósmy pokazuje zatem, że deklaracja ma stanowić uzupełnienie etosu akademickiego. W pierwszym odczuciu punkt ten może budzić obawy, że jest to próba zastąpienia etosu akademickiego nowym tworem, jednak treść deklaracji jasno wskazuje, że respektuje ona wartości zawarte w kodeksach akademickich. W dziewiątym punkcie deklaracji jest z kolei mowa o przejrzystości działań uczelni i upowszechnianiu dorobku. Kwestie te znajdują odzwierciedlenie w zapisach kodeksów akademickich. W tym punkcie zwrócono natomiast uwagę na mierzenie rezultatów oraz wyznaczenie koordynatora do prowadzenia tych działań. Punkty deklaracji mają charakter bardziej praktyczny, co jest cechą koncepcji społecznej odpowiedzialności uczelni, zatem na próżno szukać ich we wcześniej ustanowionych kodeksach akademickich. Treść dziesiątego punktu deklaracji jest spójna z definicją społecznej odpowiedzialności sformułowaną przez Komisję Europejską. W punkcie tym odniesiono się mianowicie do minimalizowania negatywnego wpływu na środowisko w toku działalności uczelni. Jedenasty punkt deklaracji dotyczy kwestii dialogu z interesariuszami na temat polityki społecznej odpowie- 
dzialności prowadzonej przez uczelnie. Relacje z interesariuszami mają tutaj charakter dwustronny zgodnie z teorią interesariuszy. W kodeksach akademickich mowa była jedynie o wsparciu społeczności ze strony uczelni, nie było natomiast wzmianek o relacjach dwustronnych. Ostatni, dwunasty punkt deklaracji w całości pokrywa się z zasadami zawartymi w kodeksach akademickich. Dotyczy on kierowania się etyką i odpowiedzialnością w prowadzeniu badań, dydaktyce oraz zapewnienia interesariuszom możliwości korzystania z wiedzy i dorobku naukowego uczelni. Punkt ten odnosi się do klasycznego ujęcia etosu akademickiego, w ramach którego pod pojęciem wspólnoty kryje się zapewnianie dostępu do wiedzy wszystkim tym, którzy są nią zainteresowani.

\section{Zakończenie}

Refleksja nad przyszłością etosu akademickiego jest bardzo istotna ze względu na jego rangę i znaczenie dla całego środowiska naukowego. Stąd też jego „erozja” wywołuje pytania o przyszłość uniwersytetu. Mnogość zmian, procesy globalizacyjne i rozwój społeczny sprawiły, że konieczne jest uzupełnienie wartości wymienianych w kodeksach akademickich.

Spadek znaczenia etosu akademickiego przy jednoczesnym wzroście zainteresowania społeczną odpowiedzialnością sprzyja refleksji, że jest to doskonała okazja, by ochronić wartości w nim zawarte. Deklaracja społecznej odpowiedzialności uczelni zawiera również punkty, które nie były eksponowane w etosie akademickim, jednak są one w zgodzie z wartościami w nim zawartymi. Punkty te dotyczą rozszerzenia odpowiedzialności uczelni na chociażby środowisko naturalne, prowadzenia dialogu $\mathrm{z}$ otoczeniem, podejmowania inicjatyw $\mathrm{w}$ ramach partnerstw z różnymi podmiotami, jak również zaangażowania w postaci wolontariatu oraz podejmowania edukacji w zakresie zrównoważonego rozwoju i innowacji społecznych, co poniekąd wynikało z wartości zawieranych w kodeksach akademickich, jednak nie zostało sformułowane wprost. Co więcej, etos akademicki ma charakter ideowy, natomiast społeczna odpowiedzialność uczelni opiera się na wartościach, przy jednoczesnym zaproponowaniu rozwiązań na poziomie zarządzania. Jej charakter jest zatem bardziej kompleksowy i przystosowany do implementacji w strategii zarządzania uczelnią. Być może dalszy rozwój i popularyzacja Deklaracji społecznej odpowiedzialności uczelni przyniesie większe zainteresowanie nią ze strony środowiska akademickiego i pozwoli dostrzec szansę na ochronę wartości zawartych w etosie akademickim. 


\section{Literatura}

Akademicki kodeks etyczny Akademii Górniczo-Hutniczej (2003), http://www.agh.edu.pl/ uczelnia/dokumenty/inne-dokumenty/kodeks-etyczny-agh/ (data dostępu: 28.12.2017).

Akademicki kodeks wartości (2003), http://www.uj.edu.pl/uniwersytet-z-collegium-medicum/kodeks-wartosci (data dostępu: 28.12.2017).

Bieliński J. (2016), Etos nauki w Polsce. Nauka akademicka, postakademicka czy przemysłowa?, XVI Ogólnopolski Zjazd Socjologiczny, 14-17 września 2016, Gdańsk.

Brzeziński J.M. (2011), Etos akademicki, „Forum Dydaktyczne: Przeszłość, Teraźniejszość, Przyszłość", nr 7-8.

Chłoń-Domińczak A., Sławiński S., Kraśniewski A., Chmielecka E. (2017), Polska Rama Kwalifikacji. Wiedza, umiejętności, kompetencje społeczne, Instytut Badań Edukacyjnych, Warszawa.

Chmielecka E. (2008), Kilka uwag o etosie i kodeksach akademickich oraz o odpowiedzialności uczelni (w:) Społeczna odpowiedzialność uczelni, red. K. Leja, Politechnika Gdańska, Gdańsk.

Chmielecka E. (2017), Autonomia, odpowiedzialność i etos środowiska akademickiego. Czy sq zależne od typu uczelni? (w:) Autonomia uczelni i środowiska akademickiego - odpowiedzialność i etos akademicki, Instytut Problemów Współczesnej Cywilizacji im. Marka Dietricha, Warszawa.

Deklaracja społecznej odpowiedzialności uczelni podpisana przez 23 uczelnie (2017), Ministerstwo Rozwoju, http://www.mr.gov.pl/strony/aktualnosci/deklaracja-spolecznej-odpowiedzialnosci-uczelni-podpisana-przez-23-uczelnie (data dostępu: 28.12.2017).

Dobre praktyki w szkołach wyższych (2007), red. A. Szostek, Fundacja Uniwersytetu Jagiellońskiego, Kraków.

Etos akademicki. Wartości i zasady postępowania przyjęte w Szkole Głównej Handlowej $w$ Warszawie (2004) (w:) Dobre obyczaje w kształceniu akademickim, red. K. Kloc, E. Chmielecka, Warszawa.

Gaweł W. (2017a), Ewolucja roli uczelni wyższych w kształtowaniu świadomości gospodarczej i społecznej studentów (w:) Problemy przeobrażeń współczesnego społeczeństwa i gospodarki, red. K. Zawieja-Żurowska, A. Waligórska-Kotfas, Państwowa Wyższa Szkoła Zawodowa w Koninie, Konin.

Gaweł W. (2017b), Projekty badawcze kierunkiem rozwoju uczelni wyższych (w:) Współczesne trendy $w$ zarzadzaniu projektami innowacyjnymi $i$ zasobami ludzkimi, red. J. Walas-Trębacz, M. Sołtysik, Fundacja Uniwersytetu Ekonomicznego w Krakowie, Kraków.

Kerr C. (2001), The Uses of the University, Harvard University Press, Cambridge.

Kodeks etyki pracowników Politechniki Wrocławskiej (2016), http://pwr.edu.pl/pracownicy/kodeks-etyki (data dostępu: 28.12.2017).

Morawski R. (2016), Nauka w czasach biurokracji (w:) Inżynier z duszq humanisty, red. J. Sośnicka, Wydawnictwo Naukowe Politechniki Łódzkiej, Łódź.

Morawski R. (2017), Autonomia, odpowiedzialność i etos środowiska akademickiego. Czy sq zależne od typu uczelni? (w:) Autonomia uczelni $i$ środowiska akademickiego - odpowiedzialność i etos akademicki, Instytut Problemów Współczesnej Cywilizacji im. Marka Dietricha, Warszawa. 
Nowakowski P.T. (2011), O etycznych kanonach pracy nauczyciela akademickiego i próbach ich kodyfikowania, „Studia z Teorii Wychowania”, vol. 2, nr 1(2).

Program rozwoju szkolnictwa wyższego do 2020 r., cz. II: Misja społeczna uniwersytetu w XXI wieku (2015), red. A Szostek, Fundacja Rektorów Polskich, Warszawa.

Szacki J. (1989), Z życia nauki i z życia Towarzystwa. Nauka i etyka, Roczniki Towarzystwa Naukowego Warszawskiego, nr 52.

Sztompka P. (2016), Uniwersytet w przestrzeni społecznej, „Zarządzanie Publiczne”, nr 2(36), https://doi.org/10.15678/ZP.2016.36.2.03.

Sztompka P. (2017), Autonomia: fundament kultury akademickiej (w:) Autonomia uczelni $i$ środowiska akademickiego - odpowiedzialność $i$ etos akademicki, Instytut Problemów Współczesnej Cywilizacji im. Marka Dietricha, Warszawa.

\section{Higher Education in Poland and the CSR Declaration as Reinforcement of Academic Ethos}

(Abstract)

On 16 November 2017, 23 Polish higher education institutions signed a CSR Declaration. The declaration includes twelve points stipulating the principles related to CSR in higher education. The reasons for the growing significance of the concept of CSR in higher education can be attributed to the diminishing importance of academic ethos. The values that constitute academic ethos should be a guiding light for activities undertaken by universities, so their diminishing significance is a cause for concern. Developing the concept of CSR in higher education is an opportunity to keep these values alive. The article explores the values common for academic ethos and CSR in the Higher Education Declaration. The analysis leads to the conclusion that the popularisation of the concept of CSR in higher education has been reinforced by the declaration, which largely refers to academic ethos.

Keywords: social responsibility, university, values, mission, academic ethos. 